\title{
Law Enforcement of Illegal Fishing Crimes in the Indonesian Sea Region
}

\author{
Handoyo Supeno \\ Doctoral Law Student at Fakultas Hukum Universitas 17 Agustus 1945 Surabaya \\ Slamet Suhartono \\ Lecturer of Fakultas Hukum Universitas 17 Agustus 1945 Surabaya \\ Otto Yudianto \\ Lecturer of Fakultas Hukum Universitas 17 Agustus 1945 Surabaya
}

\begin{abstract}
Indonesia is a strategic position with the sea area $2 / 3$ from the mainland, with an area of $6,166,163 \mathrm{~km}^{2}$. This position is very strategic and profitable in Indonesia in all aspects, especially the economic field. The Indonesian sea region is a line of trade shipping in the Asia region. The Indonesian sea also has abundant marine wealth, which becomes another country's magnet for illegal fishing. In addition, it also becomes the place of various other criminal acts, such as trafficking, illegal drugs trafficking, weapons smuggling, and so forth. As a sovereign country, Indonesia has the authority to enforce its maritime sovereignty, including the law enforcement in the sea area. According to Act No. 2 of 2002 of Police of Republic of Indonesia, the law enforcement in the sea is constitutionally the responsibility of the national Police of the Republic of Indonesia, in this case Water Police Unit(Sat Polair). In addition, it is also the duty of Marine Security Agency (BAKAMLA) under Act No. 32 year 2014 about Marine. The existence of these two law enforcement agencies in the sea in its implementation poses a conflict of authority, because each has the same duties, functions, and authority in the law enforcement at sea. The conflict of authority occurs as a result of each of these institutions interpreting their own duties, functions and authorities, so that the objectives and objectives of law enforcement are not achieved in accordance with the expectations of the government. Therefore, there should be a rearrangement of the institutions that are owned by each institution, to avoid overlappings of authority.
\end{abstract}

Keyword: law enforcement, illegal fishing, sea area, overlapping authority

DOI: $10.7176 / J L P G / 86-12$

Publication date:June $30^{\text {th }} 2019$

\section{Preliminary}

The sea is the gift of God Almighty to all mankind. For Indonesia, the sea stores enormous natural wealth that can be utilized to improve the welfare of the people. For Indonesia, the Sea has four strategic meanings, namely as: (1) The supply of natural resources and media to make a living, (2) Uniting Nation, (3) The Defence media; and (4) Media connection.

The strategic location of Indonesia which is located between the Indian Ocean and the Pacific Ocean, and flanked by two continents, namely Asia and Australia, makes the position of Indonesia as a strategic country in the Asian region, especially in the field of trade and shipping. Therefore, the stability of the marine region is crucial for the economic continuity of the Asian regions, even the world. If the sea is not safe, then the economy of the sea countries will be disturbed by". ${ }^{1}$

In addition to having four strategic meanings and the potential of a very high economic value, which is estimated to reach USD 500 billion (4,500 trillion) per year, ${ }^{2}$ Indonesia's marine region also has potential bilateral conflict triggers with neighboring countries Borders and is directly adjacent to the Indonesian Sea region. This vast marine region, is also prone to be the place of various criminal acts, which is very detrimental, such as: illegal fishing, wood smuggling, sea piracy, human trafficking, terrorism, weapons smuggling, illegal drugs trafficking, etc.

Prevention and response of various criminal acts is not easy to do, because the area of Indonesian sea water reaches $6,166,163 \mathrm{~km}^{2}$, consisting of 0.3 million $\mathrm{km}^{2}$ of territorial sea, 2.8 million $\mathrm{km}^{2}$ of archipelago waters, and 2.7 million $\mathrm{km}^{2}$ Indonesia Exclusive Economic Zone"3. Limitation of law enforcement officers and limitations of the law enforcement infrastructure is certainly the main reason of the weakness of law enforcement.

The efforts to safeguard Indonesia's marine territory have been conducted with various law enforcement

\footnotetext{
${ }^{1}$ Slamet Soebiyanto, "Keamanan Nasional ditinjau dari Perspektif Tugas TNI Angkatan Laut", Majalah Patriot, 2007, p. 10.

${ }^{2}$ Ibid

${ }^{3}$ Suhaidi, Perlindungan Terhadap Lingkungan Laut dari Pencemaran yang Bersumber dari Kapal: Konsekwensi Penerapan Hak Pelayaran Internasional Melalui Perairan Indonesia, Pustaka Bangsa Press, Jakarta, 2004, p. 2.
} 
efforts by the National Police of the Republic of Indonesia, through Water Police Unit (Sat Polair). Police as law enforcement officers are at the forefront of law enforcement and play an important and strategic role in securing the maritime environment. Police function is one of the functions of State Government in the field of security maintenance and public order, law enforcement, protection, and service to the community.

The police function is affirmed in article 13 of Act No. 2 of 2002 concerning State Police of the Republic of Indonesia, which mentions that the main task of the Police is: 1) maintaining the security and order of the community, 2) enforcing Law, 3) providing protection and service to the community. The police coordinate, monitor and provide technical guidance for special police, civil servants investigators and some other forms of private security.

In addition to Polair, security of the sea is also carried out by the government Security Coordination Agency (BAKORKAMLA) based on presidential Regulation No. 81 year 2005 on the Marine Security Coordinating Board (BAKORKAMLA), which is the legal basis of the Organization's operations. ${ }^{1}$ This institution is composed of various ministries and State institutions related to the Marine. However, the effort is not yet sufficiently compacted and not optimal, since each of the ministries and State institutions involved in it works independently and is influenced by each other.

In 2014 enacted Act number 32 year 2014 about the sea, which in article 59 paragraph (3) giving the legal foundation for the establishment of the Maritime Security Agency (BAKAMLA) as a refinement while replacing Bakorkamla. Teotally, section 59 paragraph (3) specifies: "In the framework of law enforcement in the territory of the Indonesian jurisdiction, especially in carrying out security and safety patrol in Indonesia's territorial waters, established the Security Agency of The Sea (BAKAMLA) Republic of Indonesia ". The provisions of Article 59 paragraph (3), are realized by the establishment of the Sea Security Agency (BAKAMLA) through presidential Regulation No. 178 Year 2014.

Bakamla is a non-ministerial government institution that directly replied to the President, through a responsible minister. Bakamla has the task of conducting security and safety patrol in the territory of Indonesian jurisdiction. The function of Bakamla is governed in article 62 of Act number 32 year 2014 concerning marine. Article 3 Presidential Regulation number 178 year 2014 about the Marine Security Agency. To support the implementation of the operational authority of Bakamla, according to article 55 paragraph (1) of presidential Regulation number 178 year 2014, Bakamla can establish the Maritime Zone Security Office which aims to implement maritime security in certain areas. The establishment of Bakamla with all its duties, authorities and functions is solely done to optimize safety and security maintenance at the sea.

Law enforcement at the sea by Bakamla, operationally involving several leaders of institutions and ministries that have the authority as a leader of law enforcement functions in the sea. Several institutions and ministries involved in the law enforcement in the sea consist of: Menhankam/Pangab, Minister of Transportation, Minister of Finance, Minister of Justice and Attorney general. The existence of Bakamla consisting of various ministries and state institutions with the authority, functions and duties specified in the law and regulation of the President, in practice raises various problems that can be Influence the effectiveness of law enforcement in order to maintain security at the sea. This practical problem relates to the duties, functions, and authority of BAKAMLA in conducting criminal law enforcement at the sea, especially illegal fishing, considering in addition to BAKAMLA, in law enforcement at the sea is also done by Sat Polair.

\section{Legal Issue}

Based on the background of the problem above, the legal issue expressed in this paper is related to the arrangement of law enforcement between the Sat Polair and Bakamla against the crimes in the sea, especially illegal fishing.

\section{Discussion}

\section{a. Sea as fishery resource}

Sea as a source of fisheries in Indonesia is a source of animal protein, and exports to obtain foreign exchange for the development of the Indonesian nation. The fact shows how important the source of biological wealth in this matter is fisheries for Indonesia". ${ }^{2}$ Therefore, security at sea is an integral part of the effort to defend the sovereignty of the State at sea, which is the authority of the Government as the personification of the state to conduct the management and administration of Indonesian territorial waters (a right to government) ". ${ }^{3}$ Therefore, the crimes in the sea, especially illegal fishing which is detrimental to Indonesia must be prevented and addressed as early as possible.

\footnotetext{
${ }^{1} \mathrm{Ibid}, \mathrm{p} .2$.

2 Hasyim Djalal, Perjuangan Indonesia Di Bidang Hukum Laut, BinaCipta, Bandung, 1979, p. 3.

${ }^{3}$ Eka Martiana Wulansari, "Penegakan Hukum di Laut Dengan Sistem Single Agency Multi Tasks", dalam Jurnal Rechts Vinding Online.
} 
Criminal law enforcement efforts at sea, especially illegal fishing has actually been and continues to be done. Even under the Ministry of Fisheries and the Marine, led by Susi Pudjiastuti has carried out a decisive action by drowning hundreds of ships belonging to illegal fishing perpetrators to defraud the perpetrators. This effort does not discourage perpetrators of criminal acts at sea, especially illegal fishing, but instead the improvement of quantity.

This fact gives rise to the impression that criminal law enforcement in the sea, especially illegal fishing has less serious attention from the government. There is even a assumption that many criminal acts of illegal fishing, caused by the weak law enforcement in the sea. Such a assumption is not entirely wrong, because law enforcement in the sea is characterized by the obscurity of regulatory authority duties, and functions, various ministries and State institutions that become the element of Bakamla and Sat Polair on the other parties.

The obscurity of the regulatory authority on the sea is to cause each of the isnpoints incorporated in the Bakamla and Sat Polair, often interpreting the authority, duties and functions of law enforcement according to the respective perception. Such conditions are exacerbated by the selfish interests of each ministry and state institutions resulting in the enforcement of law in the sea running independently, impressed not well coordinated, so that the law enforcement Not in accordance with the objectives desired by the Government and the people.

\section{b. The Authority of Sat Polair in Law Enforcement at the Sea}

In the implementation of law enforcement tasks at sea, the Police of Republic Indonesia (Sat Polair) held an important and strategic role. Law enforcement by Polair is the embodiment of one of the functions of government in the field of maintenance of security and order, protection and service to the community. This function is set out in article 13 of Act No. 2 of 2002 of the Police of the Republic Indonesia.

Article 14 Letter G Act Number 2 year 2002 about the police, it is determined that: "The Police of the Republic Indonesia is tasked with conducting investigations and investigations into all criminal acts in accordance with the criminal procedure law and regulations of other legislation ". Furthermore, in the regulation of the head of Police of the Republic of Indonesia number 21 year 2010 on organizational structure and work procedure of organizational Unit at the headquarters of the Republic of Indonesia police, it is determined, that: "Performance of duties and authority The police in the territorial waters, must be handled by the Directorate of Water Police, which is part of the Indonesian Security Preservation Board".

The performance of police water duties at the regional level is governed by the Indonesian State Police chief Regulation No. 22 of 2010 on organizational arrangement and governance at district police level, which in Article 202 paragraph (2), it is determined that: " The task of the Directorate of Aquatic Police is conducting police function in Indonesian waters ". Such functions is investigation function. In addition, police authority in investigations and investigations is also governed by the Act No. 2 of 2002 about the police, and also in various other statutory regulations governing criminal acts Particular at sea, particularly criminal acts of illegal fishing.

Criminal law enforcement at the sea, especially illegal fishing put the police as a sub-systems of the criminal justice system in Indonesia. This is as mandated by the Criminal Code Procedures (KUHAP). The criminal justice System is in principle to seek the truth of the material (substantial truth), and protect the human rights (protection of human rights). The efforts to seek the truth of the material, starting from the examination at the level of police investigation, as the main door that can determine the alleged presence and absence of criminal acts that can be held legally accountable by the perpetrator through Correct investigation and investigation of suspected criminal offence.

In carrying out the duties, functions, and authorities of law enforcement at sea, Sat Polair was under the command of the Security Maintenance Agency (hereinafter called Baharkam) the Indonesian police. In addition to answering the challenges ahead in the face of the water problem dynamics, Sat Polair also anticipates various things in order to support the vision of realizing Indonesia as the world maritime axis. This task and authority carried out as an element of the main task of the Resort Police (Polres) under the head of the Resort Police (Kapolres).

Sat Polair conducts the function of the water Police, which includes water patrol, law enforcement in the water, the construction of coastal communities and other waters, as well as search and rescue accidents in the water (SAR). Sat Polair that led by head of Water Police Unit (Sasat Polair)is responsible to the Kapolres, and in the execution of its daily duties under the control of the Vice Head of Resort Police (Wakapolres).

In law enforcement at the sea, Sat Polair coordinates, monitors, and gives technical instructions to special police, civil servants investigators and several other private security officers. The authority of Sat Polair in the enforcement of such law shall be governed in article 16 of the police ACT, which includes: a). Conducting arrest, B) detention, c) search and seizure; d) prohibit any person from leaving or entering the crime scene for the sake of investigation; brings and exposes people to investigators in order for the investigation; e) To stop suspected persons and inquire and check for identification; e) Conducting checks and foreclosures of letters; f) Calling people to be heard and examined as suspects or witnesses; g) Bringing the necessary experts in relation of the examination of the case; h) Conducting termination of investigations; i) submitting docket to the public prosecutor; j) Submitting a request directly to an authorized immigration officer at an immigration inspection in 
an urgent and abrupt state; k) Enforcing the prohibition of roadway to suspected crimes; L) Providing instruction and investigation assistance to the civil servants ' investigator and receive the results of the Investigation of Civil Servants Investigator (PPNS) to be handed over to the public prosecutor; and $\mathrm{m}$ ) Conducting other acts according to responsible law.

\section{c. The authority of BAKAMLA in law enforcement at sea}

Beside the Polair, criminal law enforcement duties at sea, is also conducted by Bakamla. Regarding to Bakamla's authority is further governed in the Presidential Decree number 178 year 2014 about Bakamla, which mentions that: Bakamla also has authority that is implemented in an integrated and unified under one command and control. The Bakamla authority pursuant to article 4 includes: a) Conducting a real pursuit; b) Dismissing, inspecting, arresting and submitting vessels to the relevant agencies authorized for the implementation of further legal proceedings; and c) Integrating security and safety information systems in Indonesian territorial waters and jurisdiction of Indonesia.

In addition, Bakamla, also has the authorities that includes: a) Drafting national policies in the field of security and safety in Indonesian water regions and jurisdiction areas of Indonesia; b) Conducting security and safety early warning system in Indonesian jurisdiction; c) Performing the guard, supervision, prevention and enforcement of violations of the law in Indonesian territorial waters and the territory jurisdiction of Indonesia; D) Respecting and monitoring the implementation of water patrols by related agencies; e) Providing technical and operational support to related agencies; f) Providing search and relief assistance in Indonesian territorial waters and the jurisdiction of the territory of Indonesia; and g) Performing other duties in the National defense system.

Bakamla is chaired by Minister of Defense/Commander of Indonesian National Armed Forces with membership arrangement consisting of: Minister of Transportation, Minister of Finance, Minister of Justice, Attorney General, police officer and chief of Staff of TNI AL. The task is to coordinate all security operations activities In the sea, solving all the problems of lawlessness in the sea, organizing cooperation with neighboring countries with the intention that the security operations in the sea is always assured the power and good results optimally.

In carrying out its duties, Bakamla is considered still has some disadvantages, namely: first related to the fact that each institution as a element Bakamla, among others: "TNI (Navy), police (Polair), Customs and Excise, unity of the Guard Sea and Coast (Directorate General of Sea Transportation), Ministry of Marine Affairs and Fisheries and Immigration, in carrying out its authority, main tasks and functions often run independently according to its authority, thus confusing the people's activities in the sea". ${ }^{1}$ This is due to the egosectoral of each institution is unclear.

In addition, the existence of BAKAMLA as a law enforcement agency at sea, raises various polemic, because the legal basis of its formation is less strong, there is no official budget support from the Government, and is militaristic. Other weaknesses also related to the MPR Decree No. VI/MPR/2000 on the separation of the Indonesian National armed Forces and the Indonesian State Police, and the MPR Decree No. VII/MPR/2000 on the role of Indonesian national armed forces and the role of police Republic of Indonesia. These weaknesses are seen from the uninclusion of the police element, so that enforcement of law in the sea can not be carried out optimally.

\section{d. Overlapping law enforcement authority at the sea}

The obscurity of the regulatory authority on the sea, involving various ministries and State institutions, led to the overlap of authority, resulting in legal uncertainty. In this case can be seen in some cases arrest perpetrators of illegal fishing criminals that ended without clarity. Not even a few perpetrators of illegal fishing criminals arrested, arrested and then in the process of investigation and investigation is released, because of the difference in interpretation of the instrument of evidence and perception of the obligations owned between Bakamla and Sat Polair. Even the existence of Bakamla has impressed the existence of the authority dualism investigation and investigation in the sea between Bakamla Sat Polair. This authority dualism causes uncertainties in the law enforcement of criminal acts at sea, especially illegal fishing.

\section{e. Law enforcement at the sea in some countries}

In some countries, law enforcement at sea is done by a special institution that is given clear authority. In the United States, in the peaceful State of the security and law enforcement authorities in the sea are conducted by United States Coast Guard/USCG, which is a military unit under the United States Department of Homeland Security. The USCG was not part of the U.S. Navy, but ships integrated into the military operations of the American Navy. USCG's presence in securing at sea concentrates on its task, which is power projection, while handling sea security, port security, and defense patrol are carried out by the Coast Guard.

In the UK, for marine security tasks formed Her Majesty's Coastguard/HMCG, whose authority concentrates on the tasks of Search and Rescue (SAR). The HMCG does not have the maintenance role of the maritime signposts that are the responsibility of Trinity House and the Northern Lighthouse Board. Likewise in

${ }^{1}$ Ibid. 
Scotland and Northern Ireland, HMCG is also unconcerned with the supervision of customs and Excise. For SAR purposes, if necessary, HMCG can rent commercial helicopters and tug boats. HMCG has several helper teams for accidents in muddy and mountainous areas, as well as some beach helper boats which are the leading coordinating bodies and public servants for search and relief efforts.

In Japan for the safeguarding and enforcement of law at sea was handed over to the Japan Coast Guard/JCG (Kaijo Ho'an-cho), which was established in 1949, known as the Maritime safety Agency. The JCG is under the supervision of the Ministry of Transportation and Public works and is responsible for the protection of Japanese coastline. JCG's duties include SAR, hydro-seanography survey and cruise traffic management. The JCG was led by a commander and two deputy commanders. The other officers under him were Dirjen, Irjen and the directors. JCG is divided into four departments, namely Administration department, Department of Technology and Equipment, Department of Hydro-Oceanography as well as the Department of Traffic cruise.

In Malaysia The Security and law enforcement duties at sea are carried out by Agensi Penguatkuasaan Maritim Malaysia/APMM (The Malaysian Maritime Enforcement Agency), also known as the Malaysian Coast Guard. The task governs the order and coordinator of search and aid operations in the offshore and the Malaysian Maritime Zone. The operating area is divided into five territorial waters consisting of 18 sea districts. Coast Guard Malaysia is not planned to be integrated into the Royal Malaysian Army.

Malaysian Coast Guard is part of the Malaysian Civil Service and responsible to the Prime Minister's department. In times of war, emergency or special circumstances, this body can be placed under the command of the TDM on the prime Minister's order. Currently, Vice Prime Minister and Defence Minister Dato ' Seri Mohd Najib bin Tun Haji Abdul Razak are responsible for MMEA. The organization is headed by a Director general appointed by the Supreme Master with the duties and responsibilities of operations, command and control and supervision. Administratively, Dirjen is responsible to the Secretary General of Prime Minister and the head of government.

Singapore's surveillance and law enforcement at sea was initially carried out by the Cost Guard. In 1993, the Coast Guard function was subsequently transferred from the Singapore Navy to Marine Police from Singapore police Force. The water Police was later restructured as a police Coast Guard (PCG), one of the few law enforcement organizations in the world that combined water policy and Coast guard duties. Authority (Police Coast Guard/PCG), specifically maintaining security and order in the coastal areas of Singapore.

\section{f. Future criminal law enforcement concepts at the sea}

During this time law enforcement at sea, can not be removed from the role of Indonesian Navy National Army (hereinafter called TNI-AL) as a major component of State defense that consistently carry the task to maintain the integrity of the region, Maintain security stability at sea, as well as protecting natural resources at sea from various forms of security disorders and lawlessness in the territorial waters of Indonesia's national jurisdiction". ${ }^{1}$

The role of the TNI-AL is affirmed in article 9 paragraph B Act No. 34 year 2004 about the Indonesian National army, which determines that the duty of the Navy is to enforce the law and maintain security in the marine region of the national jurisdiction in accordance with Statutory provisions of national law and international law that have been ratified. In carrying out its duties and authorities, the NAVY is not alone in the management and mechanism of enforcement of State sovereignty, as well as enforcement of law at sea, but rather involves several ministries and state institutions under BAKAMLA.

Furthermore, the authority of several ministries and state institutions under the BAKAMLA is the authority to conduct inspections and investigations, as well as an investigation into certain criminal acts at sea, especially illegal fishing, including Coastal areas, as well as national ports, which can be detailed as follows:

1. The Indonesian Navy(TNI AL), in charge of maintaining territorial security, the sovereignty of the NKRI territory in the sea from the threat of foreign countries;

2. Water Police (Polair), which conducts crimes investigation in Indonesian law water teritory;

3. Directorate General of Customs and Excise (P2), in charge of supervising the traffic violations of goods import/export (smuggling);

4. Directorate General of Sea Transportation (The fleet of PLP/KPLP) serves as lifeguard and law enforcement at sea;

5. Ministry of Marine Affairs and Fisheries (KKP), serving as an investigation of marine wealth and fisheries;

6. Ministry of Energy and Mineral resources, in charge of supervising mining business;

7. Ministry of Culture and Tourism, in charge of supervising cultural heritage objects and security to the safety of tourists, sustainability, and environmental quality;

8. Ministry of Law and Human rights, serving as supervisory, immigration and immigration investigation;

9. The Attorney General of Indonesia is responsible for prosecution of criminal acts occurring in the region throughout Indonesia.

10. Ministry of Agriculture, responsible for securing animal, fish, and plant and quarantine;

\footnotetext{
${ }^{1}$ Bambang Usadi, “Sistem Penegakan Hukum dalam RUU Kelautan”, dalam Jurnal Maritim, 8 September 2014.
} 
11. Ministry of Environment in Environmental affairs;

12. Ministry of Forestry, in charge of law enforcement in the field of forestry including animal smuggling and illegal logging;

13. Ministry of Health, in charge of conducting medical supervision/distribution on board includes crew members, passengers, goods, and cargo. ${ }^{1}$

The complexity of the authority involving various frankities and state institutions in the law enforcement in the sea, until now still raises various problems that have not been resolved. Each law enforcement agency in the Sea performs its functions and duties are not well coordinated, making it difficult to realize legal certainty, and justice in the handling of criminal acts in the sea.

The mechanisms of law enforcement which include investigations, investigations, and prosecution, and the judiciary are not clearly conceptualized, either in the legislation, or in the implementation. The complexity of criminal law enforcement at sea, also raises the process of incurring the protracted criminal offense. It's not infrequently perpetrators of criminal acts in the sea, especially illegal fishing is examined, interwoven, and investigated by several different agencies, on the grounds of its authority. However, in contrast, some agencies or institutions that have authority over the same territory, are reluctant to check and choose to conduct the examination separately. As a result perpetrators of criminal acts do not obtain legal certainty.

The problem of overlapping the authority between law enforcement in the sea is increasingly complex with licensing issues, such as unauthorized fishing crimes, sailing without permission, carrying forest results without permission, the search of valuable items not to permit, arrest and carry protected animals without official or unlicensed documents and activities in Indonesian waters without permission.

The issue of law enforcement is increasingly complex with the distribution of the management authority of the sea area between provincial and municipal/district areas as a result of the principle of regional autonomy that raises the debureaucratization of licensing management at and licensing management at City/district level. The principle of regional autonomy has resulted in the birth of regional claims over the sea areas contained in its jurisdiction. Because each region has the authority to publish licensing related to the utilization of marine territory activities. Based on the principle of the Contrario actus, the region needs the authority to do law enforcement in the sea, especially regarding to the licensing.

In connection with the overlap of law enforcement authorities in the sea and the complexity of licensing, it should be law enforcement in the sea and the licensing process is carried out interactively between various authorities in the sea and subject to legislation Its own. The need for this particular arrangement is based on reason, that the violation at sea is a criminal act that has its own peculiarities (special crime) that occurs only in the sea area, has its own complexity and challenges. ${ }^{2}$

Regarding to the authority of law enforcement at sea in some countries as outlined above, it is necessary to submit the opinion that law enforcement authority in the sea is handed over to the body specifically formed for it. The agency was not part or separated from the Indonesian Navy (TNI-AL) army as an army whose authority maintained the sovereignty and integrity of the territory from outside threats and interference. This sea law enforcement agency has a specially provisioned budget, and has clear authority, so that it can concentrate on the authority and security duties of the Marine region.

The clarity of law enforcement authorities in the sea is expected to end differences in perception and interpretation between ministries and State institutions involved. The Model of law enforcement at sea in some countries may be exemplary, so it is supposed that Indonesia also formed a similar institution of Coast Guard in the United States, and other countries, with authority, function, and clear and decisive tasks. If the law enforcement model is thus adopted, then the likelihood of overlapping authority may be avoided.

The establishment of a special institution such as the Coast Guard in the United States, it is authorised to enforce the law against the violation of the Sea Kanto law or enforce the law against criminal acts at sea. While the TNI-AL was given a special task and authority to maintain the security of the country that threatens the integrity of the country, and does not manage the legal safeguards of territorial waters such as illegal fishing, trafficking, smuggling, etc. The TNI-AL task focuses on the task and authority to safeguard the territorial integrity of the threat from outside the country, the violation of peaceful rights, the violation of air areas above the Indonesian sea, piracy in the sea, piracy in the sea, and so forth.

\section{Closing}

Enforcement of criminal offenses in the sea, in particular, illegal fishing crimes in Indonesia involve many kementerin and state institutions in the container Bakamla, and Sat Polair, so that there is an overlap of authority. This condition is exacerbated by egotictoral, thus resulting in no legal certainty in the enforcement of criminal acts in the sea. In connection with this it is advisable to do a reconstruction arrangement of law enforcement

\footnotetext{
${ }^{1} \mathrm{Ibid}$.

${ }^{2}$ Ibid.
} 
authorities in the sea by positioning each ministry and state institutions involved in accordance with its authority, fundamental duties and functions clearly. New bodies or institutions such as coast guards in America and other countries are important to do. The new institution was given special authority to enforce the Law against the Criminal act in the sea, while the TNI-AL is carrying out principal tasks and functions to secure territorial integrity of the country from possible threats from outside the region.

\section{References}

Arief, Barda Nawawi, Kebijakan Hukum Pidana, PT. Citra Aditya Bakti, Bandung, 2002.

Gautama, Sudargo, Pengertian Tentang Negara Hukum, Alumni, Bandung, 1973.

Hadjon, Philipus M., Tentang Wewenang, Fakultas Hukum Universitas Airlangga, Surabaya, 1998.

Hersutanto, Begi, Problematika Sinergi dalam Grand Design Nasional Kebijakan Keamanan Laut, Penerbit CSIS, Jakarta, 2007.

Kusumastanto, Tridoyo, Ocean Policy dalam Membangun Negeri Bahari di Era Otonomi Daerah, PT. Gramedia Pustaka Utama, Jakarta, 2003.

Marlina dan Faisal Riza, Aspek Hukum Peran Masyarakat dalam Mencegah Tindak Pidana Perikanan, PT. SOFMEDIA, Jakarta, 2013.

Marzuki, Peter Mahmud, Penelitian Hukum, Kencana Prenada Media Group, Jakarta, 2009

Siombo, Marhaeni Ria, Hukum Perikanan Nasional dan Internasional, PT Gramedia Pustaka Utama, Jakarta, 2010.

Stoud, HD dalam Ridwan HR, Hukum Administrasi Negara, Raja Grafindo Persada, Jakarta, 2006

Supriadi dan Ali Muddin, Hukum Perikanan di Indonesia, Sinar Grafika, Jakarta, 2011

Thontowi, Jawahir \& Pranoto Iskandar, Hukum Internasional Kontemporer, Refika Adhitama, Jakarta, 2006

Jurnal/Paper/Mass Media

Adwani, "Perlindungan Sumber Daya Perikanan Laut sebagai Bentuk Tanggung Jawab Pemda di Perairan laut Wilayah Provinsi Aceh", Jurnal Media Hukum, Vol. 18, No. 2, Fak. Hukum UMY, Yokyakarta, 2012.

Kementerian Kelautan dan Perikanan Republik Indonesia, Laporan Kementerian Kelautan dan Perikanan Republik Indonesia Tahun 2014,: Sekretaris Jenderal KKP RI, Jakarta 2014.

Lewirissa, Yanti Amelia, "Praktek Illegal Fishing di Perairan Maluku Sebagai Tindak Pidana Ekonomi”, Jurnal Sasi, Vol. 16. No. 3 Juli-September 2010, Universitas Pattimura, Maluku.

Manan, Bagir dalam Philipus M. Hadjon, Tentang Wewenang, YURIDIKA, No. 5\&6 Tahun XII, SeptemberDesember, 1997.

Soebiyanto, Slamet, "Keamanan Nasional ditinjau dari Perspektif Tugas TNI Angkatan Laut", Majalah Patriot, 2007.

Wulansari, Eka Martiana, "Penegakan Hukum di Laut Dengan Sistem Single Agency Multi Tasks", dalam Jurnal Rechts Vinding Online. 